\title{
The social and economic effects of introducing reverse mortgages in Chile
}

\author{
José Luis Ruiz, Pablo Tapia and José Donoso
}

\begin{abstract}
This study simulates the social and economic effects of introducing reverse mortgages in Chile. It uses the 2009 Social Protection Survey and recent simulation methodologies to analyse the monetary gain associated with taking out such a loan, which is paid in periodic instalments over the homeowner's lifetime. Eligible individuals are retired homeowners, who account for $70 \%$ of the older population. Monies received increase exponentially depending on the age at which the reverse mortgage is taken out. Lastly, the increase in liquidity has significant social potential, as it could reduce the poverty rate in the target group by $15 \%$.
\end{abstract}

\section{Key words}

Housing, housing finance, mortgages, pensions, retirement, prices, economic aspects, mathematical models, social aspects, Chile

\section{JEL classification}

G21, G22, G28

\section{Authors}

José Luis Ruiz Vergara is an assistant professor at the School of Management of the University of Chile. Email: jlruiz@fen.uchile.cl.

Pablo Tapia Griñen is an assistant professor at the School of Management of the University of Chile. Email: ptapia@fen.uchile.cl.

José Donoso Salas holds a Master's degree in Finance from the University of Chile. Email: sjdonososa@fen.chile.cl. 


\section{Introduction}

In recent decades, global population trends have shown increases in longevity and in the share of older persons as a percentage of the total population. Data from the National Institute of Statistics (INE) of Chile show that in 1950, persons aged 65 and over accounted for $4 \%$ of Chile's population, a number that has continued to grow and is projected to reach $22 \%$ in 2025 . Consequently, persons in this age group are gaining increasing importance in the design of public policy and place pressure on the funding of pension systems. This situation becomes urgent when one considers that the pensions received by Chileans are lower than other countries in the Organization for Economic Cooperation and Development (OECD) and that $70 \%$ of the population considers them insufficient to maintain an adequate standard of living (Presidential Advisory Commission on the Pension System, 2015).

One alternative that can help to improve pensioners' living standards is the reverse mortgage. Broadly speaking, a reverse mortgage is a financial product aimed at retired homeowners, whereby a financial institution agrees to pay homeowners a monthly amount for as long as they live; upon their death, ownership of the property passes to the lender unless the heirs return the full amount paid. The main purpose of this instrument is to free up some of the illiquid wealth tied to homes without the owners having to vacate their property. This brings with it a series of economic benefits, such as increased household liquidity and the acquisition of resources that complement pensions and help to reduce poverty among older persons. However, as reverse mortgages are not available in Chile, the aim of this study is to simulate their possible economic and social benefits.

We follow the methodology proposed by Ma and Deng (2013) and Wang and Kim (2014) to model monthly reverse mortgage payments for a given a house price. ${ }^{1}$ Using the revenue generated by reverse mortgages, we analyse their contribution to the household income and, at per capita level, how the payments vary depending on the age at which pensioners take out a reverse mortgage and to what extent this instrument affects the poverty rate of the target group.

Reverse mortgages have been analysed in Chile by Muñoz (2011) and by Alonso, Tuesta and Lamuedra (2013). This study focuses on the social potential of the reverse mortgage through simulations based on updated models, using variants such as the loan-to-value (LTV) ratio, changes in real estate prices and mortality rates, among others. This innovative approach adds to the interest of this study: the fact that this subject is widely documented in the literature it offers a reliable basis against which to compare our findings.

Our analysis shows that monthly payments from a reverse mortgage would amount to 62,508 Chilean pesos on average for contracting parties, which is an increase of $107 \%$ over the average monthly pension of 58,245 pesos received by the individuals in the sample. The monetary gain from the instrument leads to an increase in liquidity corresponding to $57 \%$ of per capita income. In addition, the evidence suggests that the older individuals are when they take out a reverse mortgage, the higher the payments they receive, as interest rates also increase with age. This means that if all eligible persons were to take out a reverse mortgage upon retirement, the poverty rates in this population group would fall by approximately $15 \%$. Raising the retirement age for women to 65 -the same age as for menwould reduce poverty even further, leading to a $19 \%$ decline.

This article is divided into six sections. Following this introduction, section II provides details on the pension situation in Chile. Section III reviews the theoretical and empirical literature on reverse mortgages and their social potential. Section IV presents the analytical framework and the simulation data and section $V$ discusses the findings of the simulations. Lastly, section VI concludes.

\footnotetext{
1 Prices correspond to the 2009 Social Protection Survey; see [online] https://www.previsionsocial.gob.cl/sps/biblioteca/encuestade-proteccion-social/bases-de-datos-eps/.
} 


\section{Pensions in Chile}

Until 1980, Chile had a pay-as-you-go pension system, in which pensions were funded through different institutions called "cajas de pensión", with differentiated rules and benefits. With population ageing and declining rates of active workers paying into the pension system rendering it insolvent, a new pension system was created in 1981. This new system comprised fully funded individual accounts for workers entering the labour market, with workers already in the old system able to opt in. Those who remained in the old system continued to contribute to it, but their were pensions financed out of general tax revenue. Workers enrolled in the new pension system pay into individual accounts managed by Pension Fund Administrators (AFPs), responsible for collecting, registering and investing pension contributions. AFPs also pay benefits through programmed withdrawals, ${ }^{2}$ while lifetime income payments are made by life insurance companies. ${ }^{3}$

The main objective of any pension system is to guarantee a stable income for workers at the end of their working life, and this income should correspond to their earnings during their active life. The former pay-as-you-go system offered replacement rates of around $70 \%$ to those meeting the requisite conditions. ${ }^{4}$ The current system has a number of advantages over the pay-as-you-go system; however, this model alone cannot resolve the issue of financing old age in countries where income distribution is unequal, as is the case in Chile (Office of the Superintendent of Pensions, 2010).

After three decades of the fully funded system, it was observed that a significant portion of the population had insufficient savings to afford a decent living in their old age. This can be explained by the low density of contributions to individual accounts (Office of the Superintendent of Pensions, 2006) and by payment differentials related to gender and other factors. The current pensions system underwent a key reform in 2008 with the introduction of a solidarity pillar that aims to fight poverty and is funded through general taxation (Office of the Superintendent of Pensions, 2010). This improvement, however, proved insufficient. The Presidential Advisory Commission on the Pension System was established in 2015 and tasked with reviewing and the pension system and proposing improvements thereto. It reported that $50 \%$ of retirees received pensions below 82,650 pesos, with a significant gender gap: the median pension for women stood at 42,561 pesos, while for men that figure was 112,333 pesos. Half of Chilean retirees receive at most $34 \%$ of their average income for the last 10 working years. This includes retirees under the pre-1980 pension system. Thus, it is estimated that taking into account only workers in the fully funded system retiring between 2025 and 2035, half of pensioners would earn no more than $37 \%$ of their average income for the last 10 working years. Moreover, this is extremely low compared to the average replacement rate for OECD countries which stands at $66 \%$.

Lastly, the above is closely related to the fact that $70 \%$ of Chileans believe that pension incomes are insufficient to cover adequate living standards (OECD, 2013). This led to protests in 2016, in a demand for changes to the pension model that would offer better benefits (The Economist, 2016).

\section{Literature on reverse mortgages}

One of the main dilemmas facing retired homeowners is whether to remain in their homes and accept a low retirement income, or to sell their home and use some of the proceeds for rented accommodation, using the rest as a stream of income (Bartel and Daly, 1980). Economically speaking, the latter is option is rational; however, there are significant psychological costs associated with renting and moving homes

2 See [online] https://www.spensiones.cl/portal/institucional/594/w3-propertyvalue-9924.html\#faqs.

3 See [online] https://www.spensiones.cl/portal/institucional/594/w3-propertyvalue-9924.html\#faqs.

4 Persons who contributed for less than 15 years are not entitled to pension payments. 
(Davidoff, 2010). Reverse mortgages offer a possible solution to this conundrum. This financial product, which emerged in the United States in the 1980s and has since spread to a number of countries (including Canada, Australia, Spain and Japan), allows retired homeowners to borrow money, using their homes as collateral, without having to give up residence.

Phillips and Gwin (1993) identify three categories of reverse mortgages: term reverse mortgages, which entail payments of a fixed sum for a determined period, after which the loan is repaid through the sale of the property; split-term reverse mortgages, which are similar to the first but with the difference that homeowners continue to live in the property after the prescribed term of payments, which are to be repaid when the homeowner changes residency, sells the property or dies; and lastly, tenure reverse mortgages, which are considerably more common than the previous two and consist in payments of a fixed sum until the individual, moves, sells the house or dies, for a loan amount that has a positive correlation with the age of the borrower and value of the property and a negative correlation with interest rates (Fornero, Rossi and Urzi, 2016).

It is suggested that individuals who take out reverse mortgages are older persons who are asset-rich but cash-poor, i.e. who have substantial wealth (represented by home equity) but have liquidity constraints (Moulton and others, 2015). In this sense, Nakajima and Telyukova (2017) find that take-up rates of the instrument are higher among those with low income, who own expensive homes, have outstanding mortgages, live on their own and are in poor health.

Simulations of reverse mortgages were carried out in different countries to determine their potential before they were put into effect. The results have been mixed. One of the most relevant studies with regard to reverse mortgage simulations is Mayer and Simons (1994), conducted in the early stages of the use of this instrument in the United States, in which the authors claim that reverse mortgages could reduce poverty in the target group by about three quarters. The authors convert the value of the house to a lifetime annuity with monthly payments (tenure). However, owing to a lack of data and advanced methodologies, the authors assumed random property values and loan-to-value ratios. The latter variable, which corresponds to the percentage of the home that can be used as collateral, is the most questionable: the authors set the value at $75 \%$, while subsequent studies calculate it mathematically, resulting in lower values.

Kutty (1998) conducts a study of reverse mortgages already contracted in the United States. Using tenure reverse mortgages as a basis, he argues that if all households in the target group were to contract such a loan, less than one-third would be lifted out of poverty. In the United Kingdom, Hancook (1998) uses the same methodology as Kutty (1998) to model the effect of the implementation of reverse mortgage schemes and concludes that poverty would be reduced by less than $5 \%$. The differences in findings can be partially attributed to the fact that reverse mortgage income is tax-free in the United States but is subject to taxation in the United Kingdom (Ong, 2008).

Moscarola and others (2015) analyse the potential social gain to be obtained from the development of reverse mortgages in European countries where the instrument has yet to be introduced. The authors use three scenarios with arbitrarily-selected interest rates and two scenarios each with a different percentage of the property used as collateral to simulate the reduction in vulnerability in the target group. Spain and Belgium have the greatest potential, with poverty reduction peaking at close to $25 \%$. Poverty could be reduced by more than $10 \%$ in France and Italy, but that rate would be lower in the other countries studied (Switzerland, Austria, the Netherlands, Germany and Denmark).

In Chile, Muñoz (2011) argues that if the entire target group took out a reverse mortgage, poverty would fall by $88 \%$. However, this study is not based on a tenure reverse mortgage, but a split-term reverse mortgage. Furthermore, it does not take into account the increased liquidity created by the instrument in per capita terms, as most international studies do, nor does it include a disagreggation of the findings in distinct target groups. Fuentes and Moris (2014) examine the legal feasibility of introducing 
reverse mortgages in Chile, concluding that the current legal environment, which lent itself to effective drafting of contracts, and the existence of suitable legal mechanisms to protect contracting parties created favourable conditions.

The present study is based on the methodology applied by Ma and Deng (2013) and Wang and Kim (2014), who introduce the principle of insurance pricing. This principle involves a simulation that avoids losses to the lender in the event that the borrower's loan balance exceeds the value of the home at a given time, as occurs when the property value appreciates less than expected or the contracting party lives longer than estimated: this takes into account the relationship between mortgage insurance premiums and expected losses to the lender. As previous studies have not addressed this relationship, its importance has been overlooked. If financial institutions are allowed to define monthly payments at the equilibrium point where the expected values of the insurance premiums received are equal to the value of expected losses, monthly payments would be more realistic, which plays a key role in motivating financial institutions to participate in this type of market. However, as the simulation method used by these authors was not intended to analyse the social impact of reverse mortgages, the present study is ground-breaking in this regard.

Lastly, despite the theoretical potential of reverse mortgages, demand for and use of the instrument are lower than expected (Davidoff, Gerhard and Post, 2017). In the United States, only 2.1\% of eligible homeowners had reverse mortgage loans in 2011, the highest level of demand to date (Nakajima and Telyukova, 2017). Davidoff, Gerhard and Post (2017) argue that this is because target groups may find the instrument difficult to understand. This is upheld by Moulton and others (2015), who maintain that the take-up of reverse mortgages is low because seniors shy away from complicated financial instruments or do not fully understand what they entail.

\section{Methodology and data}

\section{Analytical framework}

We use a tenure reverse mortgage, which is widely documented and provides a reliable platform for comparing our findings, to calculate monthly payments. We then follow Ma and Deng (2013) and Wang and Kim (2014), in which monthly payments are calculated using the house price at the time the loan is contracted. A random house price is selected in order to model the change in monthly payments depending on the age group to which the homeowner belongs when a reverse mortgage is taken out, for a property of the same value. We apply the same method, instead using the real value of the home that is being used as collateral.

House prices were based on the 2009 Social Protection Survey (EPS), which is representative of the population and has detailed and reliable information on the pensioners making up the target group. Notwithstanding the above, the value of the property at the time of each individual's retirement is required for the model. To this end, we apply the simulation used in Ma and Deng (2013) and Wang and Kim (2014), adding one prior step to obtain the home price at retirement by using the 2009 values for each individual. This study presents the methodology used by those authors for calculating monthly payments, with extensive use of life tables (Office of the Superintendent of Pensions, 2009a).

The algorithm used to simulate the monthly payments includes the following:

(i) the house price according to the 2009 Social Protection Survey.

(ii) the estimated house price at the time of retirement.

(iii) the estimated house price at the term of the mortgage. 
(iv) the loan-to-value ratio.

(v) the estimated monthly payments (using life tables).

The simulation begins with the house price based on 2009 values as the base variable, which is obtained as described in section IV.3. We then proceed as follows:

(a) Based on the 2009 house for individual $i,\left(P_{2009, i}\right)$, the price of the home at the time of each individual's retirement $\left(P_{j, i}\right)$ is estimated based on the methodology developed by Szymanoski (1994). For a description of this methodology, see annex A1.

$$
P_{J, i}=\frac{P_{2009, i}}{\exp \left(\mu \cdot t_{i}+0,5 \cdot \sigma^{2} \cdot t_{i}\right)}
$$

Where $\mu$ corresponds to the average annual growth of property prices (Central Bank of Chile) in the economy and $\sigma^{2}$ represents the variation in that growth rate, while $t_{i}$ indicates the number of years elapsed between the retirement of individual $i$ and 2009, according to information obtained from 2009 Survey.

(b) Once the house price at the time of retirement has been obtained, we calculate the price at the term of the contract $\left(P_{T, i}\right)$, approximate to the price of the property when the individual $i$ meets his or her life expectancy (in accordance with Szymanoski, 1994).

$$
P_{T, i}=P_{J, i} \cdot \exp \left(\mu \cdot T_{i}+0,5 \cdot \sigma^{2} \cdot T_{i}\right)=\frac{P_{2009, i} \cdot \exp \left(\mu \cdot T_{i}+0,5 \cdot \sigma^{2} \cdot T_{i}\right)}{\exp \left(\mu \cdot t_{i}+0,5 \cdot \sigma^{2} \cdot t_{i}\right)}
$$

In this case, $T_{i}$ represents the expected duration of the contract in years - that is, the life expectancy of $i$ - less the retirement age, which is obtained by combining data from the National Institute of Statistics (2010a) and the mortality tables from the Office of the Superintendent of Pensions. Similarly, values for life expectancy and age at retirement will depend on the sex of the individual.

(c) We obtain the loan-to-value (LTV) ratio, which is the maximum percentage of the home's value at the age of retirement that can be used as collateral, as seen in equation (3).

$$
L T V_{i}=\frac{P_{T, i} /(1+r)^{T_{i}}}{P_{J, i}}
$$

Where $r$ is the discount rate of the loan, which comprises the linear sum of the country's risk-free interest rate ${ }^{5}\left(i_{l r}\right)$, the insurance premium ${ }^{6}\left(I P_{m}\right)$ and the lender's margin ${ }^{7}(L M)$. These are the elements that typify the national economy.

(d) We calculate the current loan value (CLV), understood as the loan amount disbursed by the financial institution when only a lump sum is paid on signature of the contract. This is described in equation (4), which includes the up-front insurance premium ${ }^{8}$ for the loan $\left(I P_{0}\right)$.

$$
C L V_{i}=P_{J, i} \cdot\left(L T V_{i}-I P_{0}\right)
$$

\footnotetext{
5 Monthly average of secondary market 10-year interest rates of peso-denominated bonds (BCP) tendered by the Central Bank of Chile (see [online] https://si3.bcentral.cl/Boletin/secure/boletin.aspx?idCanasta=1MRMW2951).

6 The $0.5 \%$ rate in effect in the United States market is used (Rodda and others, 2003). The same rate is used in the papers establishing the methodology applied (Wang and Kim, 2014; Ma and Deng, 2013).

7 Variable that usually ranges between $1 \%$ and 2\% (Rodda, Herbert and Lam, 2000). We use 1\%, following Wang and Kim (2014).

8 The $2 \%$ rate in effect in the United States market is used (Rodda and others, 2003). The same rate is used in the paper establishing the methodology applied (Wang and Kim, 2014).
} 
(e) According to Wang and Kim (2014), monthly payments are determined as in equation (5), where represents the expected duration of the loan in months.

$$
L M_{i}=\frac{C L V_{i}}{\sum_{n=0}^{n=\left(\tau_{i}-1\right)}(1+r)^{-n}}
$$

Equation (5) gives the value of monthly payments assuming that all individuals live out their life expectancy. However, this figure is merely theoretical, as borrowers may die before or after that date. As this could give an inaccurate estimate of monthly payments, to improve the scope of the simulation, we expand equation (5) by including a discount factor that considers the probability of $i$ being alive to receive the payment in month $N,\left(p_{N, i}\right)$, assuming the individual was alive at the time the reverse mortgage was taken out, as expressed in equation (6).

$$
L M_{i}=\frac{C L V_{i}}{\sum_{N=0}^{N=T}\left[(1+r)^{-N} \cdot\left(p_{N, i}\right)\right]}
$$

Where the term $T$ represents the period in which the probability of survival falls to 0 .

Regarding equation (6), it is important to bear in mind that in this study we obtain $p_{N, i}$ from the life tables of the Chilean pension system for 2009 (see annex A2), where the probability of dying is given in annual intervals and not monthly intervals as required by the model. We will therefore assume that the probability that an individual is alive in a given year is equal to the probability that the same individual is alive in every month of that year. The Chilean pension system life tables to 2009 are the basis for determining the threshold value $T$ (110 years for both sexes). This corresponds to a loan duration of $T=540$ months for an individual retiring at 65 and $T=600$ months for an individual retiring at 60 .

\section{Economic parameters}

Knowledge of specific parameters of the Chilean economy is required for our model:

\section{Discount rate on reverse mortgages}

In the specialized literature, the discount rate used to calculate reverse mortgage payments is obtained by adding a risk-free interest rate, usually for a 10-year period, together with a differential representing the lender's margin and another to cover a monthly insurance premium paid over the life of the loan. The Central Bank of Chile 10-year interest rate in pesos (BCP-10), with an annual average of $5.67 \%$ in 2009, was used as the risk-free rate. Annual rates of $1 \%$ and $0.5 \%$ (Rodda, Hebbert and Lam, 2000) will be used for the lender's margin and monthly insurance premium, respectively, as practised for reverse mortgages in the United States.

\section{Initial cost of the loan}

This corresponds to the value of the property at the time of borrowing, multiplied by an up-front insurance premium of 2\% (used in Ma and Deng (2013) and in Wang and Kim (2014)).

\section{Mean and standard deviation of percentage change in house prices}

The variables related to movement in house prices are obtained using the real estate price index provided by the Central Bank of Chile, available from 2003 to 2014. To that end, we use the simple average of the variation in the annual index and the standard deviation over the period, which previously stood at $4.4 \%$ and $2.9 \%$, respectively. 


\section{Life expectancy and life tables}

The life tables for Chile as of 2009 were used to determine the life expectancy of the individuals in our sample. The life expectancy for men is 76 years, while for women it is 81 years (INE, 2010b). The survival probabilities of individuals over the term of the loan are estimated using the life tables for lifetime income pensions in Chile in 2009, disaggregated by sex. These tables are included in annex A2.

There are gender differences in the probability of survival. Data on the probability of survival for men retiring at 65 and for women retiring at 60 and 65, taking 110 as the upper age limit for both genders, show that at each age men are less likely to be alive than women. This difference is greatest in the median ages of the life span analysed (see figure 1).

Figure 1

Survival probability, by sex and age at retirement

(Percentages)

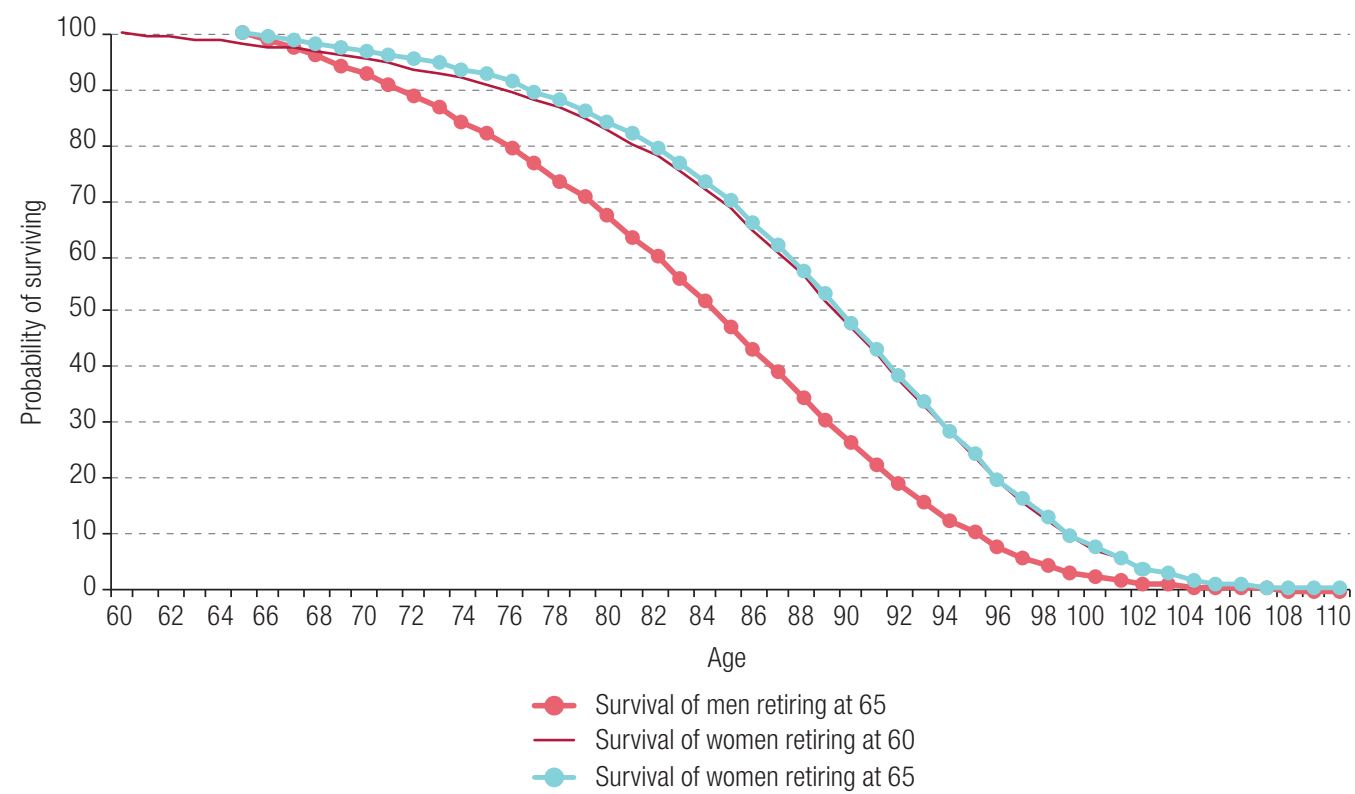

Source: Prepared by the authors, on the basis of Office of the Superintendent of Pensions, "Compendio de Normas del Sistema de Pensiones, Libro III, Título X, Tablas de Mortalidad, Anexo № 5", Santiago, 2009 [online] http://www.spensiones.cl/ portal/compendio/596/w3-propertyvalue-4350.html.

\section{Data}

The Social Protection Survey (EPS) is a longitudinal survey that is representative of the population; its 2009 edition compiles various observations on some 16,000 households throughout Chile. It has played a key role in the analysis and design of public policies in Chile, ${ }^{9}$ specifically those on pensions, and is therefore a vital source of information for our study. The sample population, comprising only the target group for reverse mortgages - namely homeowners of retirement age (women aged 60 and over and men aged 65 and over) - was extracted from this Survey.

The following question was asked in the Survey to determine the price of homes: "If you were to sell your house today, how much would it be worth?" ${ }^{10}$ The answer to that question is hereinafter

\footnotetext{
9 The Presidential Advisory Council for Pension Reform (2015) was able to identify shortcomings in pension policy thanks to the Survey.

10 Question D17 of the 2009 Social Protection Survey.
} 
referred to as the "house price". However, because it is based on a personal appreciation, it may be biased. To correct this bias, we assume that individuals' mobility between regions is low and we thus classify individuals by their region of birth and by deciles according to the expansion factor, forming homogeneous groups based on property value. Thus, for each individual, the average value for the corresponding segment is imputed as the house price. This solves possible bias and also covers the observations of individuals who did not know or did not answer the question on the value of their home. In addition, the values given to the homes in the sample are not normally distributed. This is corrected by removing data for house prices above percentile 97.5, which corresponds to house prices above 100 million pesos. The resulting distribution is shown in figure 2 . This is also represented in table 1 showing a comparison between the variables house price and imputed house price, which is the value of the house based on the aforementioned adjustments.

Figure 2

Distribution of house prices in Chile

(Percentages)

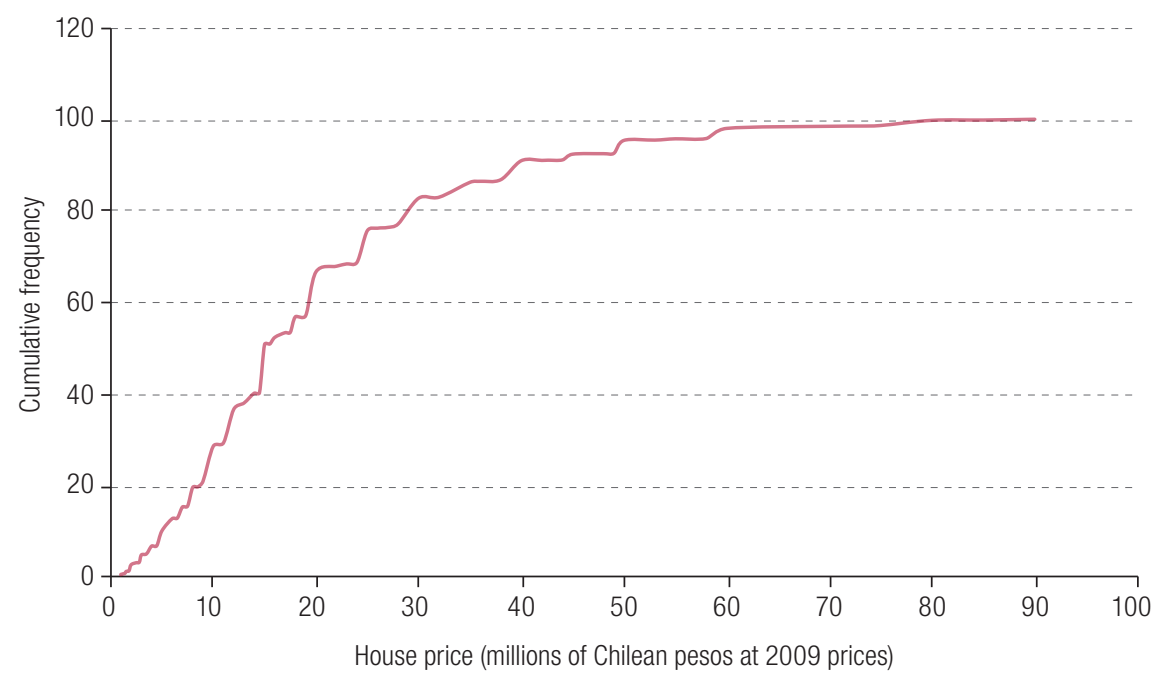

Source: Prepared by the authors, on the basis of Social Protection Survey, 2009.

Table 1

Comparison of house prices and imputed house prices

\begin{tabular}{lccccc}
\hline Variable & Observations & Mean & $\begin{array}{r}\text { Standard } \\
\text { deviation }\end{array}$ & Minimum & Maximum \\
\hline House price (millions of pesos at 2009 prices) & 1752 & 20.60 & 15.00 & 1.00 & 90.00 \\
\hline Imputed house price (millions of pesos at 2009 prices) & 2627 & 20.40 & 4.11 & 2.50 & 50.00 \\
\hline
\end{tabular}

Source: Prepared by the authors, on the basis of Social Protection Survey, 2009.

Note: Based on a sample of 2,627 observations representing a population of 1,623,326 individuals.

Lastly, 2,627 observations were selected from this process, representing a population of $1,623,326$ households; women make up $59.1 \%$ of the population and the average age is 71 years. Of the respondents, 65\% are heads of household with an average household income of 103,749 pesos. The average per capita income is 34,724 pesos (see table in annex A3). In light of the above, $86.25 \%$ of the sample are below the poverty line. ${ }^{11}$

\footnotetext{
11 Urban poverty line in terms of people living in income (absolute) poverty in Chile (see [online] http://observatorio.ministeriodesarrollosocial. gob.cl/casen/casen_def_pobreza.php), which stands at 64,134 pesos per capita.
} 


\section{Empirical section}

To simulate the monthly payments, we must first establish house prices at the time of retirement and at the term of the loan, and the initial price of homes imputed to 2009 in the Social Protection Survey, in line with the modelling in Szymanoski (1994). We note that the average property price at the time of retirement is 14 million pesos, while the average for the expected property value at the term of the contract is slightly more than 30 million pesos (see table 2). From the above, we obtain the loan-to-value (LTV) ratio, the average of which is $59.42 \%$. This value can be broken down by sex, where the average LTV for women is $53.92 \%$ and for men $72.36 \%$. The above figures are consistent with the fact that the expected duration of mortgages is lower for men, because of their later retirement age and shorter life expectancy than women.

Once we have obtained the LTV ratio, we can calculate the current loan value (CLV), understood as the amount the financial institution disburses in a lump sum to the homeowner at the time the reverse mortgage is taken out, as opposed to making monthly payments. The average CLV is 8 million pesos, which is used to calculate monthly payments, assuming that all eligible individuals take out a reverse mortgage. The average for monthly payments is 62,508 pesos, with a standard deviation of 29,760 pesos. However, when taking into account self-funded pensioners ${ }^{12}$ in the sample, the average pension income is 145,808 pesos. That income could rise by $43 \%$ if we included reverse mortgage payments. When we consider in the sample retirees receiving the solidarity pension (non-self-funded), the average pension amounts to 58,245 pesos; the addition of monthly payments from the reverse mortgages would see this income rise by $107 \%$. These large increases can be explained by the low pensions in Chile but they also show that older persons possess high volumes of illiquid wealth.

It is also appropriate to analyse reverse mortgage payments by gender, as this determines retirement age and life expectancy, bases on which the duration of the mortgage and the loan amount available to pensioners are calculated. Gender also determines the amount of the basic pension, which in turn defines the initial wealth base, since the average pension for women is 51,174 pesos, while that for men is 89,185 pesos (see table 2). This is attributable to differences in labour participation and the existing wage gap between women and men in Chile (Sáez, 2010).

Table 2

Estimate of reverse mortgage parameters

\begin{tabular}{lcrrrr}
\hline Variable & Observations & Mean & $\begin{array}{r}\text { Standard } \\
\text { deviation }\end{array}$ & Minimum & Maximum \\
\hline House price at retirement (millions of pesos at 2009 prices) & 2627 & 14.00 & 5.40 & 1.12 & 47.80 \\
\hline House price at term of loan (millions of pesos at 2009 prices) & 2627 & 31.6 & 13.60 & 1.83 & 122.00 \\
\hline Loan-to-value ratio (percentages) & 2627 & 59.42 & 8.44 & 53.92 & 72.36 \\
\hline Current loan value (millions of pesos at 2009 prices) & 2627 & 8.07 & 3.43 & 0.79 & 33.10 \\
\hline Monthly payments (pesos) & 2627 & 62508 & 29760 & 6807 & 285512 \\
\hline Monthly payments for women (pesos) & 1552 & 51174 & 20539 & 7883 & 178732 \\
\hline Monthly payments for men (pesos) & 1075 & 89158 & 31053 & 6807 & 285512 \\
\hline
\end{tabular}

Source: Prepared by the authors, on the basis of Social Protection Survey, 2009.

Note: Based on a sample of 2,627 observations representing a population of 1,623,326 individuals.

As we have mentioned, there is a five-year difference in retirement age between women and men, which affects the execution of the reverse mortgage contract because its duration is determined by age at retirement. Chilean women currently retire at 60 -we use this as the standard scenario in this study but have also analysed an alternative scenario in which women retire at the same age as men (65 years). As expected, raising women's retirement age resulted in a 55\% increase (28,221 pesos) in

12 This means the State does not contribute to their pensions. This applies to 1093 individuals ( $41 \%$ of the sample). 
monthly reverse mortgage payments and a narrowing of the gender gap by $74.3 \%$, as shown in table 3 . Therefore, financial conditions being equal, the amount received from a reverse mortgage will also be equal; this must be taken into account if this instrument is to be incorporated in public policy design.

Table 3

Analysis of monthly payments by sex and retirement age

(Chilean pesos)

\begin{tabular}{lccccc}
\hline Status & $\begin{array}{c}\text { Retirement age } \\
\text { for women }\end{array}$ & $\begin{array}{c}\text { Retirement } \\
\text { age for men }\end{array}$ & $\begin{array}{c}\text { Total monthly } \\
\text { payments }\end{array}$ & $\begin{array}{c}\text { Monthly payments } \\
\text { for women }\end{array}$ & $\begin{array}{c}\text { Monthly payments } \\
\text { for men }\end{array}$ \\
\hline Standard scenario & 60 & 65 & 62508 & 51174 & 89158 \\
\hline Alternative scenario & 65 & 65 & 82308 & 79395 & 89158 \\
\hline Variation & & & 19800 & 28221 & 0 \\
\hline
\end{tabular}

Source: Prepared by the authors, on the basis of Social Protection Survey, 2009.

Note: Based on a sample of 2,627 observations representing a population of 1,623,326 individuals.

On the basis of the above results in the standard scenario, monthly payments from reverse mortgages would be a valuable addition to household income. They have the potential to increase the household income of the target group by about 60\% on average, from 103,749 pesos to 166,258 pesos. Consequently, per capita income also increases by approximately 57\%, from 34,724 pesos to 54,537 pesos, as seen in table 4 . This affects not only the distribution of wealth but also plays a role in improving the quality of life in those households thanks to increased income.

Table 4

Impact of reverse mortgages on income (standard scenario)

(Chilean pesos)

\begin{tabular}{lcccc}
\hline Variable & Mean & Standard deviation & Minimum & Maximum \\
\hline Household income without reverse mortgage & 103749 & 136576 & 0 & 2000000 \\
\hline Household income with reverse mortgage & 166258 & 141879 & 7883 & 2121002 \\
\hline Mean variation of household income & $60.25 \%$ & & & \\
\hline Per capita income without reverse mortgage & 34724 & 49533 & 0 & 550000 \\
\hline Per capita income with reverse mortgage & 54537 & 57525 & 2037 & 519441 \\
\hline Mean variation of per capita income & $57.06 \%$ & & & \\
\hline
\end{tabular}

Source: Prepared by the authors, on the basis of Social Protection Survey, 2009.

Note: Based on a sample of 2,627 observations representing a population of 1,623,326 individuals.

After simulating the monthly payments and assuming that all eligible individuals take out a reverse mortgage, its effects on poverty in the sample can be analysed. We observe that reverse mortgages could generate a $15 \%$ reduction in poverty rates for the sample as a whole (see table 5).

Table 5

Potential effect of reverse mortgages on poverty (standard scenario) (Percentages, except for figures in left column)

\begin{tabular}{|c|c|c|c|c|}
\hline \multirow[b]{2}{*}{ Variable } & \multirow[b]{2}{*}{ Observations } & \multicolumn{2}{|c|}{ Poverty rate } & \multirow{2}{*}{$\begin{array}{l}\text { Percentage } \\
\text { reduction in poverty }\end{array}$} \\
\hline & & $\begin{array}{c}\text { Without reverse } \\
\text { mortgage }\end{array}$ & $\begin{array}{c}\text { With reverse } \\
\text { mortgage }\end{array}$ & \\
\hline Total & 2627 & 86.25 & 73.17 & 15.17 \\
\hline Contributors to pension fund administrators (AFPs) & 434 & 90.71 & 83.77 & 7.65 \\
\hline Respondent is head of household & 1935 & 81.30 & 65.24 & 19.75 \\
\hline Respondent is not head of household & 692 & 95.48 & 87.95 & 7.89 \\
\hline Women & 1552 & 88.40 & 79.64 & 9.91 \\
\hline Men & 1075 & 81.18 & 57.94 & 28.63 \\
\hline
\end{tabular}

Source: Prepared by the authors, on the basis of Social Protection Survey, 2009.

Note: Table data based on a sample of 2,627 observations representing a population of 1,623,326 individuals. 
In this sense, the potential effect is low compared to studies conducted in the United States (Mayer and Simons, 1994; Kutty, 1998), Spain and Belgium (Moscarola and others, 2015), but greater than that detected in the United Kingdom (Hancock, 1998), Denmark, Germany, Holland, Austria and Sweden (Moscarola and others, 2015). The reduction in poverty seen in our simulation falls between the levels reported for Italy and France (Moscarola and others, 2015), as shown in table 6. This indicates that our simulation model is reliable, since the projected poverty reduction is within the ranges defined in the specialized literature and this also confirms the accuracy of the economic parameters selected.

Table 6

Potential effect of reverse mortgages on poverty, by country (Percentages)

\begin{tabular}{lccl}
\hline Country & $\begin{array}{c}\text { Percentage reduction } \\
\text { in poverty }\end{array}$ & Data year & Author \\
\hline Sweden & 3 & 2012 & Moscarola and others, 2015 \\
\hline United Kingdom & 4 & 1995 & Hancock, 1998 \\
\hline Austria & 4 & 2012 & Moscarola and others, 2015 \\
\hline Netherlands & 5 & 2012 & Moscarola and others, 2015a \\
\hline Germany & 6 & 2012 & Moscarola and others, 2015 \\
\hline Denmark & 8 & 2012 & Moscarola and others, 2015 \\
\hline France & 14 & 2012 & Moscarola and others, 2015 \\
\hline Italy & 16 & 2012 & Moscarola and others, 2015a \\
\hline Belgium & 25 & 2012 & Moscarola and others, 2015 \\
\hline Spain & 27 & 2012 & Moscarola and others, 2015 \\
\hline United States & 29 & 1991 & Kutty, 1998 \\
\hline United States & 74 & 1990 & Mayer and Simons, 1994 \\
\hline
\end{tabular}

Source: Prepared by the authors.

a Values correspond to the upper limit for each country listed in the document.

If we consider only persons paying into to the AFP system, poverty is reduced by $7.65 \%$, which is a significantly smaller decrease than in the sample as a whole. This is because, although the monthly payments to AFP contributors would be $20 \%$ higher than the sample average, their initial income is close to two-thirds of the average income of the entire sample (see table 5). Poverty reduction as a result of reverse mortgages is greater among heads of household than the sample average and slightly more than twice that among other household members. The instrument's effect would therefore be smaller than initially estimated, comparable to that seen in Denmark and Germany (Moscarola and others, 2015). The impact is small but positive for just over 100,000 households.

Lastly, it is possible to isolate the gender indicator. Initial poverty is almost $10 \%$ higher among women because men's per capita income is $50 \%$ higher than women's. As table 7 shows, in the standard scenario women receive much lower reverse mortgage payments than their male counterparts, resulting in poverty reduction of $9.91 \%$ among women compared with $28.63 \%$ among men. Therefore, if taking out a reverse mortgage is included in the decision to retire, it becomes imperative to ensure equal financial conditions for both men and women, because although the instrument will improve the well-being of retirees and their households, it could also accentuate gender-based wealth gaps.

When women's retirement age is raised, the instrument's social potential leads to a $5.31 \%$ fall in poverty among women, which is greater than the standard scenario but still lower than that among men. This widens the percentage reduction in poverty across the sample by $3.81 \%$. 
Table 7

Potential effect of reverse mortgages on poverty by sex and age at retirement (Percentages in the three rightmost columns)

\begin{tabular}{lcccrc}
\hline Status & $\begin{array}{c}\text { Retirement age } \\
\text { for women }\end{array}$ & $\begin{array}{c}\text { Retirement age } \\
\text { for men }\end{array}$ & $\begin{array}{c}\text { Percentage reduction } \\
\text { in total poverty }\end{array}$ & $\begin{array}{c}\text { Percentage } \\
\text { reduction in poverty } \\
\text { among women }\end{array}$ & $\begin{array}{c}\text { Percentage } \\
\text { reduction in poverty } \\
\text { among men }\end{array}$ \\
\hline Standard scenario & 60 & 65 & 15.17 & 9.91 & 28.63 \\
\hline Alternative scenario & 65 & 65 & 18.98 & 15.22 & 5.31 \\
\hline Variation & & & 3.81 & 0.00 \\
\hline
\end{tabular}

Source: Prepared by the authors, on the basis of Social Protection Survey, 2009.

Note: Based on a sample of 2,627 observations representing a population of 1,623,326 individuals.

Our findings may seem encouraging, but it must be borne in mind that they were obtained assuming that all qualifying persons took out reverse mortgages, which is unrealistic. Indeed, the likely outcome of reverse mortgages on poverty reduction is not as expected. Davidoff, Gerhard and Post (2017) and Nakajima and Telyukova (2017) argue that only 1.7\% of eligible individuals in the United States do, in fact, take out reverse mortgages; furthermore, they are far more popular among homeowners who are alone, low-income, in poor health, and whose properties are more expensive than the average. Therefore, if we focus on this group only - that is, those most likely to take out reverse mortgages - the present study shows that poverty is reduced by close to $2 \%$. This is because the individuals in this segment are so poor to begin with that monthly payments are insufficient to lift many of them out of poverty, but they do increase liquidity and, thus, the well-being of those who take out reverse mortgages. However, consideration must be given to the fact that our calculations are based solely on conditions observed in the present and not what could occur in the future, such as future income, family support networks or possible subventions.

\section{Analysis by age group}

Our above analysis is based on the assumption that individuals take out a reverse mortgage upon retirement, but they are free to do so at any time after their retirement date. However, the older the individual entering into the contract, the more effects there are on the monthly payments. First, taking out a reverse mortgage at an older age reduces the number of payment periods that can be expected, therefore increasing the amount of each payment. This, in turn, reduces the discount on the loan-to-value (LTV) ratio, which rises as individuals present a lower risk to the lender. Both lead to an increase in the monthly payment. This is nevertheless offset by a lower appreciation of the property, thus decreasing the LTV ratio.

In the specialized literature, there is a positive relation between the age at which the transaction is originated and the monthly payments (Ma and Deng, 2013). The aim of this section is therefore to simulate how monthly payments would vary depending on the age group to which a representative individual taking out a reverse mortgage in Chile belongs. For this purpose, a non-gender-specific life table is used, as shown in table A2.1 of annex A2.

Two cases are presented: in the first (see table 8), the price of the home at origination of the reverse mortgage is the average house price at the time of retirement of the individuals in the sample, i.e. 14 million pesos at 2009 prices. We then analyse how the monthly payments would vary if a representative individual owning a property of this value took out a reverse mortgage at $65,70,75$ or 80 years of age (see table 8 ). 
Table 8

Case 1: analysis of reverse mortgages by age group

\begin{tabular}{lrrrr}
\hline \multicolumn{4}{c}{ Imputed house price of 14 million pesos at 2009 prices } & \\
\hline Age when taking out reverse mortgage & 65 & 70 & 75 & 80 \\
\hline Imputed house price (millions of pesos at 2009 prices) & 14.00 & 14.00 & 14.00 & 14.00 \\
\hline Expected house price at term of loan (millions of pesos at 2009 prices) & 32.70 & 26.10 & 21.00 & 16.80 \\
\hline Loan-to-value ratio (percentages) & 57.9 & 66.25 & 77.19 & 89.36 \\
\hline Current loan value (millions of pesos at 2009 prices) & 7.73 & 8.99 & 10.50 & 12.20 \\
\hline Monthly payments (pesos) & 62387 & 80179 & 107080 & 149793 \\
\hline
\end{tabular}

Source: Prepared by the authors, on the basis of Social Protection Survey, 2009.

As the age at origination increases, the expected value of the home at the term of the loan decreases, while the LTV expands. This means that the increase in the latter variable is the dominant effect. In view of the above, the current loan value rises, which is enhanced by the shorter duration of the contract, thus leading to higher monthly payments at increasing rates. This is clearly shown in figure 3: there is a positive relationship between monthly, average and marginal payments and age at origination. A representative individual taking out a reverse mortgage at age 65 would receive periodic monthly payments of 62,387 pesos, which would gradually increase to 149,796 pesos if the mortgage is taken out at age 80. Further details on payments can be found in annex A4.

Figure 3

Case 1: monthly payments

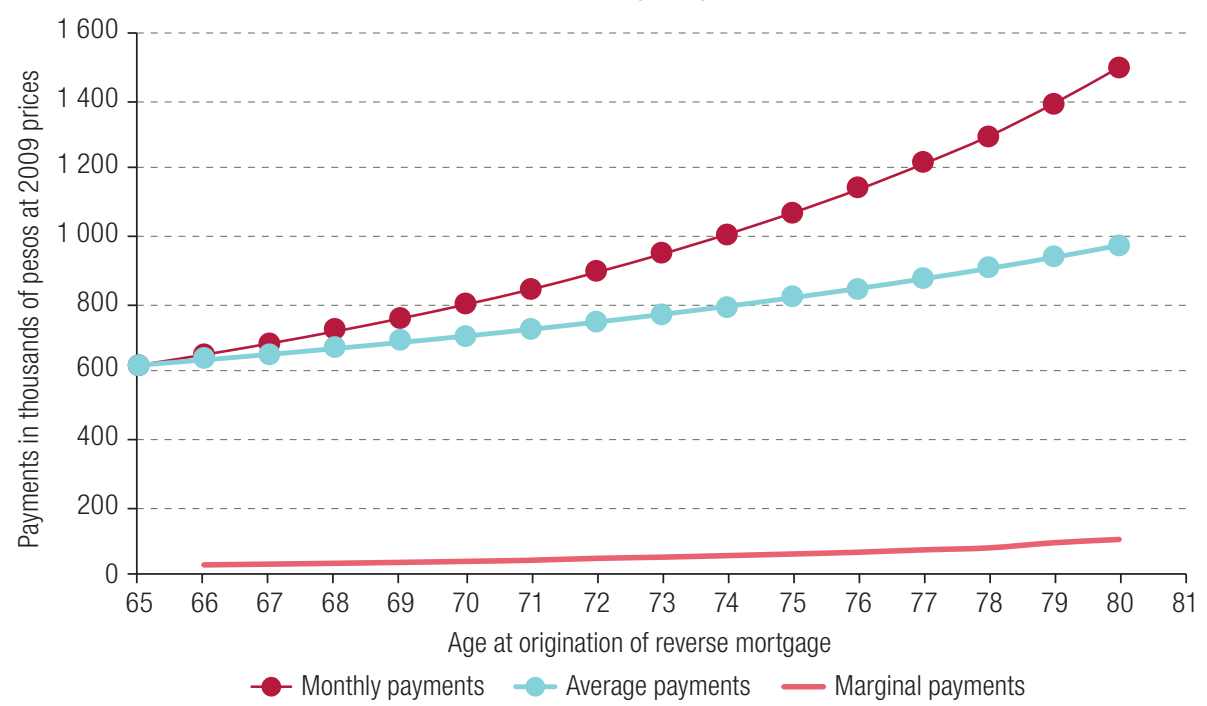

Source: Prepared by the authors, on the basis of Social Protection Survey, 2009.

In the second case (see table 9 and annex A1), the same methodology is used but we consider the initial value of the home as the average house price imputed to 2009, i.e. 20.04 million pesos, maintaining the loan-to-value ratio at each age and the rate of increase of monthly payments. Specifically, an individual retiring at 65 would receive an additional 90,907 pesos per month from a reverse mortgage and that figure that would increase to 218,270 pesos if the mortgage is taken out at 80 years (see figure 4 and annex A4). Thus, if this instrument is introduced, there will be dispersion in payments owing to the distribution of the age at which reverse mortgages are taken out. The distribution of house prices, which will depend on future appreciation, will also lead to dispersion. 
Table 9

Case 2: analysis of reverse mortgages by age group

\begin{tabular}{lrrrr}
\hline \multicolumn{4}{c}{ Imputed house price of 20.04 million pes0s at 2009 prices } & \\
\hline Age when taking out reverse mortgage & 65 & 70 & 75 & 80 \\
\hline Imputed house price (millions of pesos at 2009 prices) & 20.04 & 20.04 & 20.04 & 20.04 \\
\hline Expected house price at term of loan (millions of pesos at 2009 prices) & 47.60 & 38.01 & 30.60 & 24.50 \\
\hline Loan-to-value ratio (percentages) & 57.19 & 66.25 & 77.19 & 89.36 \\
\hline Current loan value (millions of pesos at 2009 prices) & 11.30 & 13.10 & 15.3 & 17.80 \\
\hline Monthly payments (pesos) & 90907 & 116832 & 156031 & 218270 \\
\hline
\end{tabular}

Source: Prepared by the authors, on the basis of Social Protection Survey, 2009.

Figure 4

Case 2: monthly payments

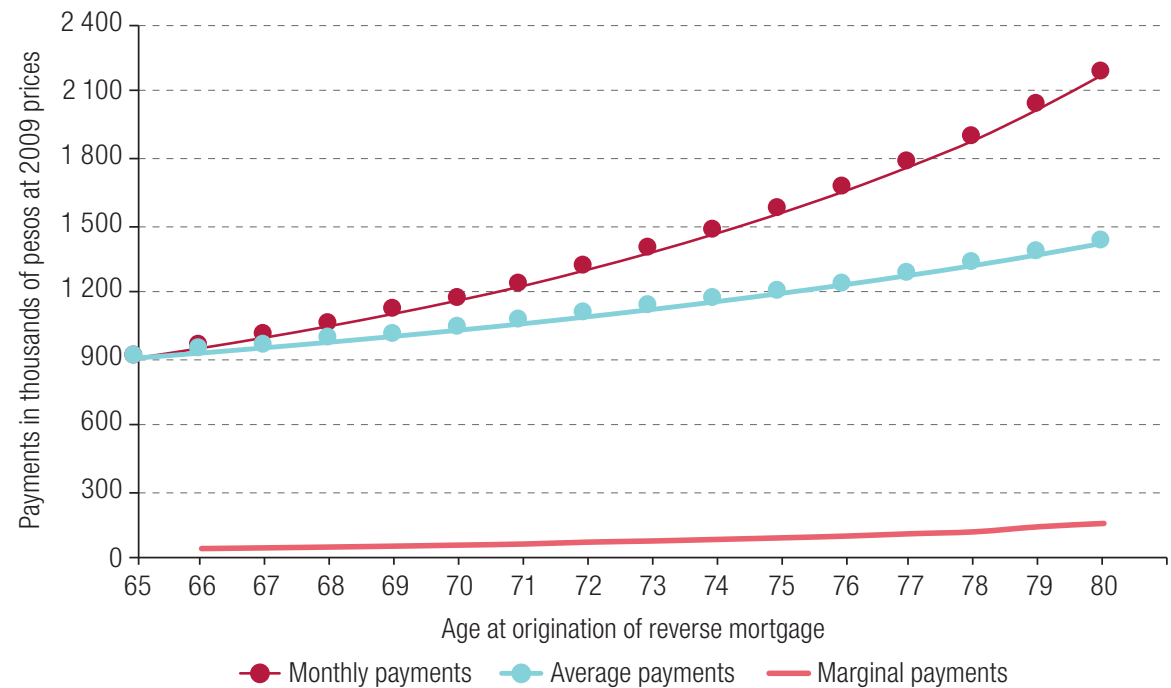

Source: Prepared by the authors, on the basis of Social Protection Survey, 2009.

\section{Conclusions}

Our study simulated the social and economic potential of introducing reverse mortgages for pensioners in Chile. We used the methodology proposed by Ma and Deng (2013) and Wang and Kim (2014), with some innovations such as the use of life tables from Chile, as well as data on house prices taken from the 2009 Social Protection Survey, which is highly representative of the population and linked to pension systems. A sample of 1,623,326 pensioners was used, representing approximately $9 \%$ of the adult population in Chile (Office of the Superintendent of Pensions, 2009a). The implementation of reverse mortgages will not resolve income poverty among older persons in Chile, but it can help homeowners, who could use it as collateral to enhance their economic independence by recovering some illiquid wealth.

We conclude that the increase in liquidity that comes with taking out a reverse mortgage reduces the percentage of the older population living in poverty. If all qualifying individuals took out a reverse mortgage, the poverty rate would decline by $15 \%$; when we restrict the sample to pensioners contributing to the current fully funded system, the poverty rate is reduced by $7.65 \%$. However, the poverty rate declines by $2 \%$ if we consider only the characteristics of the population among which reverse mortgages have been most popular where implemented (Davidoff and others, 2017; Nakajima and Telyukova, 2017), such as being alone, low-income, in poor health and having a property worth more 
than the average. These results are in line with the ranges found in the specialized literature, confirming the reliability of our findings - albeit only at a trend level - because random events are incompatible with the predictive capacity we seek.

We find that with the introduction of reverse mortgages at retirement, individuals could use on average $59 \%$ of their property as collateral, receiving constant monthly payments of 62,508 pesos, which is equivalent to $60 \%$ of the average income of households with retirees. This represents a $57 \%$ increase in retirees' per capita income. However, analysis of monthly payments reveals a gender gap, as women receive $42.6 \%$ (37,984 pesos) less than men. This difference stems from women's higher life expectancy and lower retirement age, which increases the duration of their mortgages. However, raising their retirement age to 65 narrows the gender gap narrows to 10.9\% (9,763 pesos). This indicates that if reverse mortgages were introduced as public policy, it would be necessary to ensure equal financial conditions for both men and women; failing this, although reverse mortgages will improve the well-being of retirees and their households, they could accentuate gender-based wealth gaps.

From another standpoint, our simulations made it possible to analyse how monthly payments would vary according to the age at origination of the reverse mortgage. An individual taking out such a mortgage at age 65 can use 57\% of the home's value as collateral; that figure climbs to $89 \%$ if the individual takes out a mortgage at 80 , which illustrates a positive correlation between the amount received through a reverse mortgage and the age at which it is taken out. Therefore, if this instrument is to be introduced in a public policy context, account must be taken of the dispersion that will result in mortgage payments owing to the distribution in the age of the contract. The distribution of house prices, which will depend on future appreciation, will also lead to dispersion. The diversity that these elements bring to the financial instrument means that more than one type of financial institution may be interested in offering reverse mortgages.

In summary, the findings presented in this study show that reverse mortgages can be useful in increasing liquidity for pensioners. This is important in a context where $70 \%$ of Chileans hold that pensions are insufficient to maintain an adequate standard of living in old age. Moreover, we illustrate the significant social potential in terms of poverty reduction, which could lead to undeniable gains in well-being for the target group. What matters most in the use of reverse mortgages is that older persons have access to credit and thus increase their income, without detriment to their current economic situation. However, consideration should be given to the debtor's heirs, as this instrument is a mortgage and does not involve a transfer of ownership. As this could lead to a conflict of interest between the two parties, there is a need for legislation that offers the necessary protection to both heirs and creditors (Fuentes and Moris, 2014).

\section{Bibliography}

Alonso, J., D. Tuesta and M. Lamuedra (2013), "Potencialidad del desarrollo de hipotecas inversas como complemento pensionario: el caso de Chile", Working Paper, No. 9, Madrid, Banco Bilbao Vizcaya Argentaria (BBVA).

Bartel, H. and M. Daly (1980), "Reverse annuity mortgages as a source of retirement income", Canadian Public Policy/Analyse de Politiques, vol. 6, No. 4, Toronto, University of Toronto Press.

Central Bank of Chile (2017), "Base de datos estadísticos. Indicadores sectoriales" [online] https://si3.bcentral. $\mathrm{cl} /$ Siete/secure/cuadros/arboles.aspx.

Comisión Asesora Presidencial sobre el Sistema de Pensiones (2015), Informe final, Santiago [online] http:// www.comision-pensiones.cl/Informe_final_CP_2015.pdf.

Davidoff, T. (2010), "Interest accumulation in retirement home equity products", Working Paper, Vancouver, University of British Columbia.

Davidoff, T., P. Gerhard and T. Post (2017), "Reverse mortgages: what homeowners (don't) know and how it matters", Journal of Economic Behavior \& Organization, vol. 133, Amsterdam, Elsevier. 
Fornero, E., M. Rossi and M. Urzì (2016), "Explaining why, right or wrong, (Italian) households do not like reverse mortgages", Journal of Pension Economics \& Finance, vol. 15, No. 2, Cambridge, Cambridge University Press.

Fuentes, M. and D. Moris (2014), "El futuro de la hipoteca inversa en Chile", undergraduate dissertation, Santiago, University of Chile.

Hancook, R. (1998), "Can housing wealth alleviate poverty among Britain's older population?", Fiscal Studies, vol. 19, No. 3, Hoboken, Wiley.

INE (National Institute of Statistics) (2010a), Boletín informativo. Enfoque estadístico hombres y mujeres en Chile, Santiago.

(2010b), Compendio estadístico año 2010, Santiago.

INE/ECLAC (National Institute of Statistics/Economic Commission for Latin America and the Caribbean) (n/d), Estimaciones y proyecciones de población por sexo y edad. Total país 1950-2050, Santiago.

Kutty, N. (1998), "The scope for poverty alleviation among elderly home-owners in the United States through reverse mortgages", Urban Studies, vol. 35, No. 1, Thousand Oaks, Sage.

Ma, S. and Y. Deng (2013), "Evaluation of reverse mortgage programs in Korea", Seoul Journal of Business, vol. 19, No. 1, Seoul, Seoul National University.

Mayer, C. and K. Simons (1994), "Reverse mortgages and the liquidity of housing wealth", Real Estate Economics, vol. 22, No. 2, Hoboken, Wiley.

Moscarola, F. and others (2015), "Reverse mortgage: a tool to reduce old age poverty without sacrificing social inclusion", Ageing in Europe - Supporting Policies for an Inclusive Society, A. Börsch-Supan and others (eds.), Berlin, Walter De Gruyter.

Moulton, S. and others (2015), "Who gets a reverse mortgage? Identifying household level determinants of U.S. reverse mortgage choices", paper presented at the twenty-second session of the Conference of the European Real Estate Society, Istanbul, 24-27 June.

Muñoz, M. (2011), "Hipoteca revertida en Chile: una alternativa para la reducción de la pobreza", master's thesis, Santiago, University of Chile.

Nakajima, M. and I. Telyukova (2017), "Reverse mortgage loans: a quantitative analysis", The Journal of Finance, vol. 72, No. 2, Hoboken, Wiley.

OECD (Organization for Economic Cooperation and Development) (2013), Pensions at a Glance 2013. OECD and G20 Indicators, Paris.

Office of the Superintendent of Pensions (2010), El sistema de pensiones en Chile, Santiago.

__(2009a), "Compendio de normas del sistema de pensiones, Libro III, Título X, Tablas de mortalidad” [online] http://www.spensiones.cl/portal/compendio/596/w3-propertyvalue-4350.html.

(2009b), "Compendio de Normas del Sistema de Pensiones, Libro III, Título X, Tablas de Mortalidad, Anexo N5", Santiago [online] http://www.spensiones.cl/portal/compendio/596/w3-propertyvalue-4350.html. (2006), El sistema de pensiones en Chile, Santiago.

Ong, R. (2008), "Unlocking housing equity through reverse mortgages: the case of elderly homeowners in Australia", European Journal of Housing Policy, vol. 8, No. 1, Abingdon, Taylor \& Francis.

Phillips, W. and S. Gwin (1993), "Reverse mortgages", Transactions of the Society of Actuaries, No. 44, Schaumburg, Society of Actuaries.

Rodda, D., C. Herbert and H. Lam (2000), Evaluation Report of FHA's Home Equity Conversion Mortgage Insurance Demonstration, Abt Associates Inc., March.

Rodda, D. and others (2003), Refinancing Premium, National Loan Limit, and Long-Term Care Premium Waiver for FHA's HECM Program, Cambridge, U.S. Department of Housing and Urban Development.

Sáez, R. (2010), "La OCDE y el ingreso de Chile", Estudios Internacionales, vol. 43, No. 166, Santiago, University of Chile.

Szymanoski, E. (1994), "Risk and the home equity conversion mortgage", Real Estate Economics, vol. 22, No. 2, Hoboken, Wiley.

The Economist (2016), "The perils of not saving", London, 27 August.

Wang, P. and J. Kim (2014), "The value of reverse mortgage loans: case study of the Chinese market", Journal of Asian Finance, Economics and Business, vol. 1, No. 4, Korea Distribution Science Association. 


\section{Annex A1}

\section{Modelling of house prices at different periods}

To perform the modelling for this study, we must know the price of houses in periods outside the sampling period. Specifically, we must estimate house prices at the term of the mortgage (period subsequent to the sample) and, the price at the time of retirement (period prior to the sample). To do this, we follow Szymanoski's model (1994), which is detailed below.

We define the following variables:

$$
\begin{gathered}
H_{t}: \text { House price in year } t \\
H_{0}: \text { House price in year } t=0 \text { initial }
\end{gathered}
$$

Let us assume the percentage $H_{t}$ with respect to $H_{0}$ is $X_{t}$ :

$$
X_{t}=\frac{H_{t}}{H_{0}}
$$

Then:

$$
x: \text { Random variable of the set of observations } X_{t}
$$

Applying the natural logarithm to $X_{t}$ we obtain the percentage change in the house price between the initial period and random period " $t$ ":

$$
Y_{t}=\ln \left(X_{t}\right) \rightarrow X_{t}=\exp \left(Y_{t}\right)
$$

Where:

$$
y: \text { Random variable of the set of observations } Y_{t}
$$

Using the exponential function $g(a)=\exp (a)$ we have:

$$
g(y)=\exp (y) \rightarrow E(x)=E(\exp (y))=E(g(Y))
$$

Here, Szymanoski (1994) argues that long-term house price trends can be modelled by a geometric Brownian motion (GBM) process. Consequently, we assume that $Y_{t}$ is a GBM, which implies that in the period " $t$ ", $Y_{t}$ has a mean of $\mu \cdot t$ and a standard deviation of $\sqrt[\sigma]{t}$, which depicts normal distribution. At the same time, the above means that $X_{t}$ is defined as a GBM with a log-normal distribution.

Consequently, we know that since $F(y)$ is the probability function of " $y$ " and $f(y)$ is the density function of " $y$ ", then:

$$
E(g(y))=\int_{-\infty}^{+\infty} g(y) d F(y)=\int_{-\infty}^{+\infty} g(y) f(y) d y
$$

As stated, variable " $y$ " follows a normal distribution, which means that $f(y)$ is a normally distributed density distribution with a mean of $\mu$ and standard deviation of $\sigma$.

$$
f(y)=\frac{1}{\sigma \sqrt{2 \pi}} \exp \left[-\frac{1}{2}\left(\frac{y-\mu}{\sigma}\right)^{2}\right]
$$


Replacing (II) in (I):

$$
E(g(y))=E(\exp (y))=\frac{1}{\sigma \sqrt{2 \pi}} \int_{-\infty}^{+\infty} \exp (y) \cdot \exp \left[-\frac{1}{2}\left(\frac{y-\mu}{\sigma}\right)^{2}\right] d y
$$

We standardize the above and replace " $y$ " with $(y-\mu) / \sigma$, obtaining the following:

$$
E(\exp (y))=\exp \left(\mu+0,5 \sigma^{2}\right) \cdot\left(\frac{1}{\sqrt{2 \pi}}\right) \int_{-\infty}^{+\infty} \exp \left[-\frac{1}{2}(y-\sigma)^{2}\right] d y=\exp \left(\mu+0,5 \sigma^{2}\right) \cdot \beta
$$

Where the value of $\beta$ is 1 :

$$
\beta=\left(\frac{1}{\sqrt{2 \pi}}\right) \int_{-\infty}^{+\infty} \exp \left[-\frac{1}{2}(y-\sigma)^{2}\right] d y=1
$$

Through equations $(\mathrm{IV})$ and $(\mathrm{V})$ we have:

$$
E(X)=E(\exp (y))=\exp \left(\mu+0,5 \sigma^{2}\right)
$$

Thus, assuming that $x$ is a stochastic variable, with $\mu$ and $\sigma$ as constants and time as a function, equation $(\mathrm{VI})$ is calculated as:

$$
E(x(t))=\exp \left(\mu \cdot t+0,5 \sigma^{2} \cdot t\right)
$$

We then have:

$$
\begin{array}{cc}
E(H(t))=H_{0} \cdot \exp \left(\mu \cdot t+0,5 \sigma^{2} \cdot t\right) & \forall t \geq 0 \\
E(H(t))=\frac{H_{0}}{\exp \left(\mu \cdot t+0,5 \sigma^{2} \cdot t\right)} & \forall t \leq 0
\end{array}
$$




\section{Annex A2}

\section{Life tables}

Table A2.1

Life tables for $2009^{a}$

(Ages and percentages)

\begin{tabular}{|c|c|c|c|c|c|}
\hline \multirow{3}{*}{ Age (t) } & \multicolumn{2}{|c|}{ Men } & \multicolumn{3}{|c|}{ Women } \\
\hline & \multirow{2}{*}{$Q_{t}$} & \multirow{2}{*}{$p_{t}$} & \multirow{2}{*}{$Q_{t}$} & retiring at 60 & \multirow{2}{*}{$\frac{\text { retiring at } 65}{p_{t}}$} \\
\hline & & & & $p_{t}$ & \\
\hline 60 & & & 0.31 & 1 & \\
\hline 61 & & & 0.33 & 99.69 & \\
\hline 62 & & & 0.37 & 99.36 & \\
\hline 63 & & & 0.40 & 98.99 & \\
\hline 64 & & & 0.44 & 98.60 & \\
\hline 65 & 1.24 & 1 & 0.48 & 98.16 & 1 \\
\hline 66 & 1.36 & 98.76 & 0.53 & 97.69 & 99.52 \\
\hline 67 & 1.49 & 97.42 & 0.57 & 97.17 & 98.99 \\
\hline 68 & 1.64 & 95.97 & 0.63 & 96.62 & 98.43 \\
\hline 69 & 1.81 & 94.39 & 0.69 & 96.01 & 97.81 \\
\hline 70 & 1.99 & 92.68 & 0.76 & 95.35 & 97.13 \\
\hline 71 & 2.20 & 90.84 & 0.85 & 94.62 & 96.40 \\
\hline 72 & 2.42 & 88.84 & 0.95 & 93.82 & 95.58 \\
\hline 73 & 2.66 & 86.69 & 1.08 & 92.93 & 94.67 \\
\hline 74 & 2.92 & 84.38 & 1.23 & 91.93 & 93.65 \\
\hline 75 & 3.23 & 81.92 & 1.40 & 90.79 & 92.49 \\
\hline 76 & 3.36 & 79.27 & 1.59 & 89.52 & 91.20 \\
\hline 77 & 3.91 & 76.61 & 1.82 & 88.10 & 89.75 \\
\hline 78 & 4.31 & 73.62 & 2.08 & 86.50 & 88.12 \\
\hline 79 & 4.75 & 70.45 & 2.38 & 84.70 & 86.28 \\
\hline 80 & 5.26 & 67.10 & 2.73 & 82.68 & 84.23 \\
\hline 81 & 5.87 & 63.57 & 3.14 & 80.42 & 81.93 \\
\hline 82 & 6.56 & 59.84 & 3.60 & 77.90 & 79.36 \\
\hline 83 & 7.31 & 55.91 & 4.13 & 75.10 & 76.50 \\
\hline 84 & 8.16 & 51.83 & 4.73 & 71.99 & 73.34 \\
\hline 85 & 9.08 & 47.60 & 5.41 & 68.59 & 69.87 \\
\hline 86 & 10.07 & 43.28 & 6.17 & 64.88 & 66.09 \\
\hline 87 & 11.13 & 38.92 & 7.03 & 60.87 & 62.01 \\
\hline 88 & 12.27 & 34.59 & 7.97 & 56.60 & 57.65 \\
\hline 89 & 13.46 & 30.34 & 9.01 & 52.08 & 53.06 \\
\hline 90 & 14.17 & 26.26 & 10.14 & 47.39 & 48.28 \\
\hline 91 & 16.02 & 22.54 & 11.37 & 42.59 & 43.38 \\
\hline 92 & 17.37 & 18.93 & 12.70 & 37.74 & 38.45 \\
\hline 93 & 18.75 & 15.64 & 14.12 & 32.95 & 33.57 \\
\hline 94 & 20.22 & 12.71 & 15.64 & 28.30 & 28.83 \\
\hline 95 & 21.74 & 10.14 & 17.24 & 23.87 & 24.32 \\
\hline 96 & 23.32 & 7.93 & 18.93 & 19.76 & 20.13 \\
\hline
\end{tabular}


Table A2.1 (concluded)

\begin{tabular}{|c|c|c|c|c|c|}
\hline \multirow{3}{*}{ Age $(t)$} & \multicolumn{2}{|c|}{ Men } & \multicolumn{3}{|c|}{ Women } \\
\hline & \multirow{2}{*}{$Q_{t}$} & \multirow{2}{*}{$p_{t}$} & \multirow{2}{*}{$Q_{t}$} & \multirow{2}{*}{$\frac{\text { retiring at } 60}{p_{t}}$} & \multirow{2}{*}{$\frac{\text { retiring at } 65}{p_{t}}$} \\
\hline & & & & & \\
\hline 97 & 24.93 & 6.08 & 20.72 & 16.02 & 16.32 \\
\hline 98 & 26.59 & 4.57 & 22.60 & 12.70 & 12.94 \\
\hline 99 & 28.36 & 3.35 & 24.62 & 9.83 & 10.01 \\
\hline 100 & 30.26 & 2.40 & 26.30 & 7.41 & 7.55 \\
\hline 101 & 32.26 & 1.68 & 27.71 & 5.46 & 5.56 \\
\hline 102 & 34.42 & 1.13 & 29.61 & 3.95 & 4.02 \\
\hline 103 & 36.71 & 0.74 & 31.65 & 2.78 & 2.83 \\
\hline 104 & 39.15 & 0.47 & 33.82 & 1.90 & 1.93 \\
\hline 105 & 41.76 & 0.29 & 36.15 & 1.26 & 1.28 \\
\hline 106 & 44.53 & 0.17 & 38.36 & 0.80 & 0.82 \\
\hline 107 & 47.50 & 0.09 & 41.29 & 0.49 & 0.50 \\
\hline 108 & 50.66 & 0.05 & 44.12 & 0.29 & 0.30 \\
\hline 109 & 54.02 & 0.02 & 47.16 & 0.16 & 0.17 \\
\hline 110 & 100.00 & 0.01 & 100.00 & 0.09 & 0.09 \\
\hline
\end{tabular}

Source: Prepared by the authors, on the basis of Office of the Superintendent of Pensions, "Compendio de Normas del Sistema de Pensiones, Libro III, Título X, Tablas de Mortalidad, Anexo № 5”, Santiago, 2009 [online] http://www.spensiones.cl/ portal/compendio/596/w 3-propertyvalue-4350.html.

a For the purposes of this table, as in the rest of the document, it is assumed that individuals take out a reverse mortgage at the time of their retirement.

Where:

$Q_{t}=$ Probability that individual is not alive in year $t+1$, but alive in $t$.

$p_{t}=$ Survival probability or probability that the individual is alive in year $t$, and was alive when the reverse mortgage was taken out.

For women, two values are presented for $P_{t}$. The first value is given for the current situation, with women retiring at 60 . The second corresponds to the hypothetical scenario of women retiring at the same age as men, i.e. at 65 years.

Lastly, table A2.2 shows the probability of a representative individual being alive at a random age, represented in each row of the table, and the age at origination of a reverse mortgage, between 65 and 80 years, in the columns. The values in this table correspond to the geometric average of the survival probabilities by sex, weighted by the percentage of each gender in the sample. 
Table A2.2

Survival probabilities, by age at which a representative individual takes out a reverse mortgage (Ages and percentages)

\begin{tabular}{|c|c|c|c|c|c|c|c|c|c|c|c|c|c|c|c|c|}
\hline & 65 & 66 & 67 & 68 & 69 & 70 & 71 & 72 & 73 & 74 & 75 & 76 & 77 & 78 & 79 & 80 \\
\hline 65 & 100 & & & & & & & & & & & & & & & \\
\hline 66 & 99.2 & 100 & & & & & & & & & & & & & & \\
\hline 67 & 98.3 & 99.1 & 100 & & & & & & & & & & & & & \\
\hline 68 & 97.4 & 98.2 & 99.1 & 100 & & & & & & & & & & & & \\
\hline 69 & 96.4 & 97.2 & 98.0 & 99.0 & 100 & & & & & & & & & & & \\
\hline 70 & 95.3 & 96.1 & 96.9 & 97.8 & 98.9 & 100 & & & & & & & & & & \\
\hline 71 & 94.1 & 94.8 & 95.7 & 96.6 & 97.6 & 98.7 & 100 & & & & & & & & & \\
\hline 72 & 92.8 & 93.5 & 94.3 & 95.2 & 96.2 & 97.4 & 98.6 & 100 & & & & & & & & \\
\hline 73 & 91.3 & 92.1 & 92.9 & 93.8 & 94.7 & 95.8 & 97.1 & 98.4 & 100 & & & & & & & \\
\hline 74 & 89.8 & 90.5 & 91.3 & 92.1 & 93.1 & 94.2 & 95.4 & 96.7 & 98.3 & 100 & & & & & & \\
\hline 75 & 88.0 & 88.7 & 89.5 & 90.4 & 91.3 & 92.4 & 93.6 & 94.9 & 96.4 & 98.1 & 100 & & & & & \\
\hline 76 & 86.1 & 86.8 & 87.6 & 88.4 & 89.4 & 90.4 & 91.5 & 92.9 & 94.3 & 96.0 & 97.9 & 100 & & & & \\
\hline 77 & 84.1 & 84.8 & 85.6 & 86.4 & 87.3 & 88.3 & 89.4 & 90.7 & 92.1 & 93.8 & 95.6 & 97.7 & 100 & & & \\
\hline 78 & 81.9 & 82.5 & 83.3 & 84.1 & 85.0 & 85.9 & 87.0 & 88.3 & 89.7 & 91.2 & 93.0 & 95.1 & 97.3 & 100 & & \\
\hline 79 & 79.4 & 80.1 & 80.8 & 81.6 & 82.4 & 83.4 & 84.4 & 85.6 & 87.0 & 88.5 & 90.2 & 92.2 & 94.4 & 97.0 & 100 & \\
\hline 80 & 76.8 & 77.4 & 78.1 & 78.8 & 79.7 & 80.6 & 81.6 & 82.8 & 84.1 & 85.6 & 87.2 & 89.1 & 91.3 & 93.8 & 96.7 & 100 \\
\hline 81 & 73.9 & 74.5 & 75.1 & 75.9 & 76.7 & 77.5 & 78.5 & 79.7 & 80.9 & 82.3 & 83.9 & 85.8 & 87.8 & 90.2 & 93.0 & 96.2 \\
\hline 82 & 70.7 & 71.3 & 71.9 & 72.6 & 73.4 & 74.2 & 75.2 & 76.3 & 77.5 & 78.8 & 80.4 & 82.1 & 84.1 & 86.4 & 89.1 & 92.1 \\
\hline 83 & 67.3 & 67.9 & 68.5 & 69.1 & 69.9 & 70.7 & 71.6 & 72.6 & 73.7 & 75.0 & 76.5 & 78.2 & 80.0 & 82.2 & 84.8 & 87.7 \\
\hline 84 & 63.7 & 64.2 & 64.8 & 65.4 & 66.1 & 66.8 & 67.7 & 68.7 & 69.7 & 71.0 & 72.3 & 73.9 & 75.7 & 77.8 & 80.2 & 82.9 \\
\hline 85 & 59.8 & 60.3 & 60.8 & 61.4 & 62.0 & 62.7 & 63.5 & 64.4 & 65.5 & 66.6 & 67.9 & 69.4 & 71.0 & 73.0 & 75.2 & 77.9 \\
\hline 86 & 55.7 & 56.1 & 56.6 & 57.1 & 57.7 & 58.4 & 59.1 & 60.0 & 60.9 & 62.0 & 63.2 & 64.6 & 66.1 & 68.0 & 70.0 & 72.5 \\
\hline 87 & 51.3 & 51.7 & 52.2 & 52.7 & 53.2 & 53.9 & 54.6 & 55.3 & 56.2 & 57.2 & 58.3 & 59.6 & 61.0 & 62.7 & 64.6 & 66.8 \\
\hline 88 & 46.9 & 47.2 & 47.6 & 48.1 & 48.6 & 49.2 & 49.8 & 50.5 & 51.3 & 52.2 & 53.2 & 54.4 & 55.7 & 57.2 & 59.0 & 61.0 \\
\hline 89 & 42.3 & 42.6 & 43.0 & 43.4 & 43.9 & 44.4 & 45.0 & 45.6 & 46.3 & 47.1 & 48.1 & 49.1 & 50.3 & 51.7 & 53.2 & 55.1 \\
\hline 90 & 37.7 & 38.0 & 38.4 & 38.7 & 39.1 & 39.6 & 40.1 & 40.7 & 41.3 & 42.0 & 42.8 & 43.8 & 44.8 & 46.1 & 47.5 & 49.1 \\
\hline 91 & 33.3 & 33.5 & 33.8 & 34.2 & 34.5 & 34.9 & 35.4 & 35.9 & 36.4 & 37.1 & 37.8 & 38.6 & 39.5 & 40.6 & 41.9 & 43.3 \\
\hline 92 & 28.9 & 29.1 & 29.3 & 29.6 & 29.9 & 30.3 & 30.7 & 31.1 & 31.6 & 32.2 & 32.8 & 33.5 & 34.3 & 35.2 & 36.3 & 37.6 \\
\hline 93 & 24.6 & 24.8 & 25.1 & 25.3 & 25.6 & 25.9 & 26.2 & 26.6 & 27.0 & 27.5 & 28.0 & 28.6 & 29.3 & 30.1 & 31.0 & 32.1 \\
\hline 94 & 20.7 & 20.9 & 21.0 & 21.2 & 21.5 & 21.7 & 22.0 & 22.3 & 22.7 & 23.1 & 23.5 & 24.0 & 24.6 & 25.3 & 26.0 & 27.0 \\
\hline 95 & 17.1 & 17.2 & 17.4 & 17.5 & 17.7 & 17.9 & 18.1 & 18.4 & 18.7 & 19.0 & 19.4 & 19.8 & 20.3 & 20.8 & 21.5 & 22.2 \\
\hline 96 & 13.8 & 13.9 & 14.0 & 14.2 & 14.3 & 14.5 & 14.7 & 14.9 & 15.1 & 15.4 & 15.7 & 16.0 & 16.4 & 16.9 & 17.4 & 18.0 \\
\hline 97 & 11.0 & 11.0 & 11.1 & 11.2 & 11.4 & 11.5 & 11.6 & 11.8 & 12.0 & 12.2 & 12.4 & 12.7 & 13.0 & 13.4 & 13.8 & 14.3 \\
\hline 98 & 8.5 & 8.6 & 8.6 & 8.7 & 8.8 & 8.9 & 9.0 & 9.2 & 9.3 & 9.5 & 9.6 & 9.9 & 10.1 & 10.4 & 10.7 & 11.1 \\
\hline 99 & 6.4 & 6.5 & 6.5 & 6.6 & 6.7 & 6.8 & 6.8 & 6.9 & 7.0 & 7.2 & 7.3 & 7.5 & 7.6 & 7.9 & 8.1 & 8.4 \\
\hline 100 & 4.8 & 4.8 & 4.8 & 4.9 & 4.9 & 5.0 & 5.1 & 5.1 & 5.2 & 5.3 & 5.4 & 5.5 & 5.6 & 5.8 & 6.0 & 6.2 \\
\hline 101 & 3.4 & 3.5 & 3.5 & 3.5 & 3.6 & 3.6 & 3.6 & 3.7 & 3.8 & 3.8 & 3.9 & 4.0 & 4.1 & 4.2 & 4.3 & 4.5 \\
\hline 102 & 2.4 & 2.4 & 2.5 & 2.5 & 2.5 & 2.5 & 2.6 & 2.6 & 2.6 & 2.7 & 2.7 & 2.8 & 2.9 & 2.9 & 3.0 & 3.1 \\
\hline 103 & 1.7 & 1.7 & 1.7 & 1.7 & 1.7 & 1.7 & 1.8 & 1.8 & 1.8 & 1.8 & 1.9 & 1.9 & 2.0 & 2.0 & 2.1 & 2.1 \\
\hline 104 & 1.1 & 1.1 & 1.1 & 1.1 & 1.1 & 1.1 & 1.2 & 1.2 & 1.2 & 1.2 & 1.2 & 1.3 & 1.3 & 1.3 & 1.4 & 1.4 \\
\hline 105 & 0.7 & 0.7 & 0.7 & 0.7 & 0.7 & 0.7 & 0.7 & 0.8 & 0.8 & 0.8 & 0.8 & 0.8 & 0.8 & 0.9 & 0.9 & 0.9 \\
\hline 106 & 0.4 & 0.4 & 0.4 & 0.4 & 0.4 & 0.5 & 0.5 & 0.5 & 0.5 & 0.5 & 0.5 & 0.5 & 0.5 & 0.5 & 0.5 & 0.6 \\
\hline 107 & 0.3 & 0.3 & 0.3 & 0.3 & 0.3 & 0.3 & 0.3 & 0.3 & 0.3 & 0.3 & 0.3 & 0.3 & 0.3 & 0.3 & 0.3 & 0.3 \\
\hline 108 & 0.1 & 0.1 & 0.1 & 0.1 & 0.1 & 0.2 & 0.2 & 0.2 & 0.2 & 0.2 & 0.2 & 0.2 & 0.2 & 0.2 & 0.2 & 0.2 \\
\hline 109 & 0.1 & 0.1 & 0.1 & 0.1 & 0.1 & 0.1 & 0.1 & 0.1 & 0.1 & 0.1 & 0.1 & 0.1 & 0.1 & 0.1 & 0.1 & 0.1 \\
\hline 110 & 0.0 & 0.0 & 0.0 & 0.0 & 0.0 & 0.0 & 0.0 & 0.0 & 0.0 & 0.0 & 0.0 & 0.0 & 0.0 & 0.0 & 0.0 & 0.0 \\
\hline
\end{tabular}

Source: Prepared by the authors, on the basis of Office of the Superintendent of Pensions, "Compendio de Normas del Sistema de Pensiones, Libro III, Título X, Tablas de Mortalidad, Anexo № 5", Santiago, 2009 [online] http://www.spensiones.cl/ portal/compendio/596/w 3-propertyvalue-4350.html. 


\section{Annex A3}

\section{Descriptive statistics of the sample}

Table A3.1

Descriptive statistics of the sample

\begin{tabular}{lcccc}
\hline Variable & Mean & Standard deviation & Minimum & Maximum \\
\hline Sex (Men=1) (percentages) & 40.92 & 45.76 & 0 & 1 \\
\hline Age & 71.22 & 7.96 & 60 & 96 \\
\hline Head of household (head of household=1) (percentages) & 65.09 & 47.68 & 0 & 1 \\
\hline Household income (pesos at 2009 prices) & 103.75 & 136.58 & 0 & 2000.00 \\
\hline Per capita income (pesos at 2009 prices) & 34.72 & 49.53 & 0 & 450.00 \\
\hline Poverty rate (percentages) & 86.25 & 34.44 & 0 & 1 \\
\hline Imputed house price (millions of pesos at 2009 prices) & 20.40 & 4.11 & 2.50 & 50.00
\end{tabular}

Source: Prepared by the authors, on the basis of Social Protection Survey, 2009.

Note: Based on a sample of 2,627 observations representing a population of 1,623,326 individuals. 


\section{Annex A4}

\section{Reverse mortgage payments by age at origination}

Table A4.1

Reverse mortgage payments by age at origination

(Chilean pesos)

\begin{tabular}{ccc}
\hline House price at retirement & 14.00 millions of pesos at 2009 prices & 20.04 millions of pesos at 2009 prices \\
\hline Age at origination & Monthly payments - case 1 & Monthly payments - case 2 \\
\hline 65 & 62387 & 907375 \\
\hline 66 & 65453 & 100166 \\
\hline 67 & 68741 & 105312 \\
\hline 68 & 72273 & 110850 \\
\hline 69 & 76074 & 116832 \\
\hline 70 & 80179 & 123297 \\
\hline 71 & 84616 & 130588 \\
\hline 72 & 89619 & 138387 \\
\hline 73 & 94972 & 146860 \\
\hline 74 & 100786 & 156031 \\
\hline 75 & 107080 & 165965 \\
\hline 76 & 113898 & 176930 \\
\hline 77 & 121423 & 188751 \\
\hline 78 & 129535 & 202790 \\
\hline 79 & 139169 & 218270 \\
\hline
\end{tabular}

Source: Prepared by the authors, on the basis of Social Protection Survey, 2009. 